\title{
O Estado republicano democrático e o ensino público da moral segundo Kant $^{1}$
}

Joel Thiago Klein - Universidade Federal do Rio Grande do Norte

\section{A relação entre filosofia da história, antropologia e política}

A filosofia política de Kant, como "doutrina do direito exercitada (als einer ausübender Rechtslehre)" (ZeF, AA 08: 370), só pode ser compreendida enquanto uma teoria que se insere num quadro mais amplo, que inclui uma antropologia e uma filosofia da história. Isso é perceptível em todos os textos nos quais Kant expõe sua filosofia política, desde os ensaios Resposta ̀̀ pergunta: o que é esclarecimento? e Ideia de uma história universal com um propósito cosmopolita até $O$ conflito das faculdades, passando por Sobre o dito comum: isso pode ser correto na teoria, mas não serve para a prática e À paz perpétua. Em todos esses textos, sua filosofia política se liga a uma antropologia

\footnotetext{
${ }^{1}$ Este trabalho recebeu apoio financeiro da CAPES/DAAD (pesquisa de curta duração) e do CNPq (Processo: 477298/2013-3, Chamada: Universal $14 / 2013)$
} 
e a uma filosofia da história, que modelam a teoria do direito, transformando-a em doutrina do direito exercitada. Falar em "exercício" é sugerir que se trata aqui de algo mais que um acúmulo gradual de experiências, colhidas aleatoriamente na história do homem ou na história individual de homens de Estado, algo que se constituiria, na perspectiva da filosofia kantiana, uma aglomeração de elementos que não produziriam uma teoria, mas apenas um acúmulo desconexo de experiências. Numa compreensão sistemática da filosofia kantiana, um acréscimo como esse deve ser realizado segundo um princípio, de modo que o exercício ocorra segundo um modelo de crescimento orgânico e não meramente agregativo de experiências ${ }^{2}$. A acumulação orgânica ocorre de acordo com o princípio teleológico e regulativo, fio condutor tanto da concepção do que é o homem quanto da condição humana na história ${ }^{3}$. Esses aspectos estão intrinsecamente ligados, e constituem a Antropologia e a filosofia kantiana da história. Percebem-se nesse caso, mais uma vez, os efeitos da concepção da revolução copernicana do pensamento aplicada à prática política: não é possível construir uma teoria sem que se tenha em mãos um conjunto de princípios que, por sua vez, não podem ser o resultado de uma mera abstração da experiência, pois são eles a condição de possibilidade da experiência entendida como um conjunto interconectado de fenômenos.

A filosofia política apresentada no Conflito das faculdades

\footnotetext{
${ }^{2}$ Sobre a concepção de sistema segundo Kant, conferir $K r V$, B 860s.

${ }^{3} \mathrm{~A}$ interpretação desenvolvida neste artigo vai além daquela de Gerhard (Gerhard, 1996, p. 483), pois vincula o Direito à experiência pragmática oferecida pela faculdade do juízo e o liga ao princípio regulativo prático da conformidade a fins, que está na base da antropologia e da filosofia da história kantianas. Sobre a validade do princípio regulativo prático da conformidade a fins ver Klein (2013a; 2014c; 2016b)
} 
relaciona-se com a disputa entre Filosofia e Direito, a qual se reduz à questão: "estará o gênero humano em constante progresso para o melhor?" (SF, AA 07: 79) Essa "questão renovada", tema central da filosofia kantiana da história, relaciona-se com a disputa de Kant com os defensores de uma suposta política prática e de uma teoria do direito abstraída da prática, que partem do pressuposto de que "importa tomar os homens como são e não como pedantes ignaros do mundo ou benévolos fantasistas, sonhando o que deveriam ser." (SF, AA 07: 80) ${ }^{4}$ Kant vai de encontro a essa posição e chama a atenção para o fato de que "o como [os homens] são deveria significar: o que fizemos deles por um constrangimento injusto, por desígnios traiçoeiros sugeridos ao governo, [tornando-os] teimosos, e inclinados à sublevação; e então, sem dúvida, quando se afrouxam um pouco as rédeas, tristes consequências se produzem que justificam a profecia dos estadistas pretensamente sábios." ( $S F$, AA 07: 80) É preciso ler essa passagem juntamente com o primeiro texto político de Kant, Resposta à pergunta: o que é Esclarecimento? Ali, Kant assinala que

o esclarecimento é a saida do homem da sua menoridade, da qual ele próprio é culpado. A menoridade é a incapacidade de se servir do entendimento sem a orientação de outrem. Tal menoridade é de sua culpa se a sua causa não reside na falta de entendimento, mas na falta de decisão e de coragem em se servir de si mesmo sem a orientação de outrem. (WA, AA 08: 35)

\footnotetext{
${ }^{4}$ Esse mesmo "conflito" também pode ser encontrado em Sobre o dito comum: isso pode ser correto na teoria mas de nada serve na prática (Cf. TP, AA 08:275f.) e À paz perpétua (ZeF, AA 08:343).
} 
Esse estado de tutela pode abarcar diversos âmbitos da vida humana, como a espiritualidade, a moralidade e o cuidado com a saúde: "Se tenho um livro que entende por mim, um diretor espiritual cuja consciência moral substitui a minha, um médico que decide a dieta por mim, etc., então não preciso me esforçar por mim mesmo." ( WA, AA 08: 35) Note-se que essa inclinação natural à passividade (cf. $I a G$, AA 08: 21) é reforçada por um contexto histórico-cultural propício e pelo interesse egoísta dos tutores afeiçoados às vantagens advindas da sua condição: "Depois de terem embrutecido os seus animais domésticos e evitado cuidadosamente que essas criaturas pacíficas ousassem dar um passo para fora da carroça em que as encerraram, mostram-lhes em seguida o perigo que as ameaça, se tentarem andar sozinhas."'(WA, AA 08: 35) Os tutores querem manter seus pupilos como menores, e tomam providências para que eles permaneçam "amarrados" e incapazes de se emancipar. Como ser esclarecido e maior não é algo simples, nem pode ser adquirido imediatamente, segue-se que "mesmo quem se libertasse [dos grilhões] só daria um salto inseguro sobre o menor fosso, por que não está habituado a esse movimento livre. São pouquíssimos, pois, os que conseguem, mediante a transformação de seu espírito, arrancar-se à menoridade e dar passos com segurança" (WA, AA 08: 36).

Há entre essas passagens e as do Conflito uma similaridade digna de nota: em ambos os textos está em questão não apenas a perspectiva de uma crítica ao indivíduo, como muitas vezes é apontado na literatura, mas também uma crítica histórica, social e institucional. Pois se, por um lado, há uma tendência humana para a comodidade e também uma responsabilidade pessoal pelo seu próprio esclarecimento, ainda maior é a res- 
ponsabilidade social e política por essa situação, que deve ser imputada, em última instância, ao homem enquanto espécie, que vive em sociedade, e não a uma suposta condição natural, a uma providência divina ou a um pecado original. É assim que deve ser lida a sentença inicial do ensaio sobre o Esclarecimento, de que a menoridade é culpa do próprio homem. Não se trata de uma culpa meramente individual, mas de uma responsabilidade do gênero humano pela forma política e social segundo a qual ele se organiza.

A partir dessa constatação, Kant critica a presença, na política, de concepções dogmáticas da história. A atividade política é de natureza tal, que além de considerar o que foi e o que é, para disso extrair lições e compreender as circunstâncias de uma ação, deve estar voltada para o futuro. Uma concepção como essa, em que a política é uma atividade focada no futuro, distancia-se de uma concepção dogmática deste (terrorista, abderitista ou eudemonista). Na concepção de Kant, a crítica serve ao mesmo tempo como meta de uma práxis política legítima.

Kant aponta para a contradição interna à concepção terrorista da história, segundo a qual há uma constante deterioração moral e social, pois no horizonte dessa concepção o gênero humano se destruiria a si mesmo, posição que não pode ser mantida sob pressupostos justificados. Por isso, ela é avessa até mesmo à razão de seus próprios partidários, como é corroborado pelo fato de que todas as narrativas históricas e culturais que adotam essa visão terrorista da história também aceitam que ela à beira do Juízo Final (SF, AA 07: 81).

A filosofia kantiana da história não sustenta seus argumentos sobre uma suposta experiência empírica auto evidente, mas em princípios racionais que permitem construir uma compreen- 
são da história que consiga ao mesmo tempo lidar com toda a multiplicidade dos fenômenos históricos e organizá-los segundo um sistema que lhes atribua sentido. O que distingue a história (Geschichte) de uma historiografia (Historie) é a noção de um sentido histórico (cf. IaG, AA 08: 30). Um sentido que se representa pelo fim assumido, e deve ser continuamente e conscientemente fortalecido e promovido por uma política que o transforme em meta. Desse modo, a política se apresenta como uma práxis cujo objetivo deve ser a manutenção de alguns aspectos da realidade e a mudança de outros, mas sempre na direção específica de um fim expresso no contínuo aperfeiçoamento das instituições e no aumento da liberdade ${ }^{5}$.

Nesse sentido, a resposta para a questão "que se quer aqui saber?" colocada no Conflito das faculdades é "um fragmento da história da humanidade e, claro está, não do passado, mas do futuro, por conseguinte uma história pré-anunciadora, que se não se guia pelas leis naturais conhecidas (como eclipses do sol e da lua) se denomina divinatória e, todavia natural (...)" (SF, AA 07: 79). Tal resposta não possui o status teórico de um conhecimento, seja prático seja teórico, pois não se funda imediatamente sobre princípios objetivos, mas apenas sobre princípios regulativos práticos, o que faz dela não um dever ou um conhecimento de uma suposta realidade, mas uma esperança; não um desejo ingênuo de melhora ou uma confiança no estado das coisas, mas uma esperança bem fundada, a meio caminho entre o plano teórico e o prático. Essa esperança é distinta daquela esperança venal de uma história eudemonista, pois se trata de um assentimento teoricamente legítimo na medida em que não contradiz o campo da experiência possível e que, além disso, se

\footnotetext{
${ }^{5}$ Ver Refl. 1523, 15:896.
} 
sustenta sobre um princípio racional, a partir do qual é possível "(...) uma expectativa fundada tanto quanto necessário para não desesperar desse seu progresso para o melhor, e fomentar, com toda a prudência e clarividência moral, a aproximação desse fim (cada um o quanto lhe toca nisso)." (Anthr., AA 06: 329) Essa expectativa "pode ser esperada com certeza moral (suficiente para o dever de cooperar com aquele fim)."(Anthr., AA 06: 329) Em outras palavras, a tese de Kant se sustenta de forma imediata sobre "meu dever inato, em todo membro da série das gerações - em que eu (enquanto homem em geral) me encontro (...) - de atuar de tal modo sobre a descendência que ela se torne sempre melhor" (TP, AA 08: 309), o qual se transforma em um tipo de esperança prática, na qual o homem "se representa ao longe como atingindo finalmente o estado em que todos os germes, que a Natureza nele pôs, podem se desenvolver plenamente e o seu destino cumprir-se aqui na terra." ( $I a G$, AA 08: 30) Essa esperança deve ser incorporada na política não como uma ideia vazia, mas como "uma tarefa que, pouco a pouco resolvida, se aproxima constantemente do seu fim" (ZeF, AA 08:386).

Essa mesma perspectiva da filosofia da história está presente também na concepção antropológica. A característica central do homem é que "ele tem um caráter que ele mesmo cria para si enquanto é capaz de se aperfeiçoar segundo os fins que ele mesmo assume; por meio disso, ele, como animal dotado da faculdade da razão (animal rationabile), pode fazer de si um animal racional (animal rationale) (...)" (Anthr. AA 06: 321). A resposta de Kant para a questão sobre "o que é o homem?", vem não de uma suposta constatação do que o homem já alcançou ou de seus feitos, mas de sua liberdade, pela qual ele pode colocar em atividade as suas disposições e faculdades. Note-se também que 
essa constatação da existência de tais faculdades e disposições não é completamente desvinculada da experiência. Kant acredita que é possível apresentar exemplos históricos que indicam o uso de três disposições distintas, a técnica, a pragmática e a moral. Ainda que esse tipo de argumentação não tenha um caráter comprobatório, num sentido teórico forte, possui um caráter corroborativo, suficiente para os propósitos práticos. É nesse horizonte que podem ser lidas as interpretações sobre a existência de um progresso moral tendo por base o proferimento de juízos desinteressados, seja no caso de Mendelssohn em relação à educação (cf. TP, AA 08: 309), seja no caso do público em relação à Revolução Francesa (cf. SF, AA 07: 85f.). A conclusão de uma antropologia crítica que afasta concepções dogmáticas a respeito daquilo que constitui o caráter da espécie humana é a seguinte:

O ser humano está destinado, por sua razão, a estar numa sociedade com seres humanos e a se cultivar, civilizar, e moralizar nela por meio das artes e ciências; e, por maior que possa ser sua propensão animal a se abandonar passivamente aos atrativos da comodidade e do bem-estar, que ele denomina de felicidade, ele está destinado a se tornar ativamente digno da humanidade na luta com os obstáculos que a rudeza de sua natureza coloca para ele. O ser humano tem, pois, de ser educado para o bem, mas aquele que deve educálo é por sua vez um ser humano que se encontra em meio à rudeza da natureza e deve realizar o de que ele mesmo necessita. Daí o constante desvio de sua destinação e os retornos repetidos a ela. (Anth., AA 06: 324) 
Ora, qualquer que seja a concepção antropológica adotada, é inegável que ela terá efeitos para a política. Uma visão estabelecida apenas sobre considerações a respeito do que o homem é, simplesmente a partir do que supostamente constitui o fenômeno da história humana, tende a acentuar alguns aspectos em detrimento de outros. Mas a pior consequência dessa "teoria perniciosa" é que ela "produz precisamente o mal que prediz, pois nela o homem é relegado à classe das máquinas vivas, às quais se deixaria apenas ainda a consciência de não serem livres, a fim de se tornarem, segundo o seu próprio juízo, os mais miseráveis de todos os seres do universo". (ZeF, AA 08: 378)

Já a antropologia crítica kantiana oferece à política a perspectiva de que a moralidade "não é causa da boa constituição do Estado, antes pelo contrário, desta última é que se deve esperar, acima de tudo, a boa formação moral de um povo" (ZeF, AA 08: 366) Dessa concepção, que aponta para o fato de que o característico da espécie humana não é uma condição moral dada, mas sua capacidade de produzir para si mesma tal condição, decorre que não se pode esperar que os indivíduos estejam esclarecidos moralmente para que o Estado republicano surja em sua plenitude, mas, ao contrário, a partir de um esforço conjunto, ainda que parcial de diversos indivíduos, e seguindo certo movimento de idas e vindas, pode-se e deve-se criar um conjunto de instituições que, por sua natureza, isto é, a partir dos princípios pelos quais são constituídas, possam formar bons cidadãos através de um processo educativo.

Isso deve ser pensado de modo histórico e dialético, pois, se não fosse assim, isto é, se as instituições políticas forem pensadas simplesmente tendo em vista aquilo que até o atual momento histórico elas produziram, sua função se reduziria simplesmente 
a manter o status quo da ordem política e social. Seria uma política amarrada ao presente, agrilhoada à contínua projeção do passado. Pode-se resumir a posição de Kant sobre a relação entre política, história e antropologia da seguinte forma: o correto não é esperar que as instituições políticas legítimas surjam após os indivíduos já estarem esclarecidos, mas sim que as instituições políticas sejam construídas, pois somente elas propiciam um esclarecimento gradual dos indivíduos, o que, por conseguinte, reflete num aprimoramento das próprias instituições.

\section{O papel do Estado no ensino público da moralidade}

O primeiro aspecto positivo da atuação do Estado com relação à formação do caráter dos seus cidadãos é que, por sua própria existência, ao exercer positivamente a coerção contra a violência recíproca dos cidadãos, ele fornece um "verniz moral" para a sociedade (cf. ZeF, AA 08: 375n). Se viver em sociedade segundo as leis de um Estado republicano não torna os indivíduos seres morais, isso gradualmente os adequa a um modo de vida que se baseia não em ações ou ordens arbitrárias determinadas por fins empíricos, mas em leis estabelecidas segundo os princípios da liberdade, dependência e igualdade da lei. Surge assim um verniz moral que, se não é ainda moral, é um passo para a moral ${ }^{6}$.

Esse verniz moral, porém, é ainda tênue e frágil, pois o desenvolvimento da cultura, das artes e das ciências, sem o esclarecimento moral dos indivíduos, tende a gerar um sem-número de

\footnotetext{
${ }^{6} \mathrm{~A}$ maioria dos comentários se restringe a apontar para essa "parte introdutória" da política no sentido de remover impedimentos para o livre desenvolvimento da moralidade. Ver por exemplo Surprenant (2007).
} 
malefícios e vícios sociais. Kant concorda com Rousseau: seria preferível "o estado de selvagens, se se deixar de lado o último estágio que a nossa espécie tem ainda de subir" (IaG, AA 08: 26), a saber, a moralização ou desenvolvimento da humanidade. Isso porque é sob a égide de uma constituição civil que se encontra um ambiente propício para o crescimento das misérias, isto é,

paralelamente ao progresso da cultura (cujo ponto mais elevado se chama luxo, quando a tendência para o supérfluo começa a prejudicar o necessário) em ambos os lados [dos dominantes e dos dominados], de um modo igualmente forte: de um lado com uma dominação por parte de outro estranho, do outro lado como uma insatisfação interior. ( $K U$, AA 05: 432)

Para Kant, esse desenvolvimento da cultura, das artes e das ciências precisa ser balizado também por um desenvolvimento da moralidade, entendida enquanto atitude que não se refere a mero comportamento externo dos indivíduos, mas que precisa estar imbuída de uma disposição de ânimo moralmente boa, visto que "todo o bem, que não está imbuído de uma disposição de ânimo (Gesinnung) moralmente boa, nada mais é do que pura aparência e penúria coruscante." ( $I a G$, AA 08: 26)

Por isso, a verdadeira política, a política legítima, é aquela que não deixa a formação moral dos cidadãos e a educação para o bem apenas ao encargo das forças de indivíduos singulares. Para Kant, está claro que não se pode esperar o progresso para o melhor de baixo para cima, isto é, o desenvolvimento não pode ser esperado "por meio da formação da juventude na instrução doméstica e, em seguida, nas escolas, desde as mais baixas às 
superiores, numa cultura intelectual e moral, reforçada pelo ensino religioso" ( $S F$, AA 07: 92). Isso não significa que a educação para a virtude não possa ou não deva ocorrer no âmbito familiar, nas comunidades ou nas escolas, mas que a atuação de indivíduos singulares em todos esses âmbitos é insuficiente, pois parte de perspectivas singulares que jamais podem alcançar o todo, isto é, o desenvolvimento moral do Estado e do povo. Por isso, segundo Kant,

o mecanismo inteiro desta educação não tem nexo algum, se não for projetado e posto em ação segundo um plano refletido do poder político soberano, de acordo com esse seu propósito, e se não se mantiver sempre também em conformidade com ele. Para tal seria, decerto, necessário que o Estado, de tempos a tempos, se reformasse a si mesmo e, tentando a evolução em vez da revolução, avançasse de modo permanente para o melhor. (SF, AA 07: 93)

Poder-se-ia alegar contra isso que tal Estado republicano, ao adotar o projeto de uma educação pública para a moralidade, se tornaria um Estado despótico, que destruiria a liberdade de seus cidadãos ${ }^{7}$. Essa interpretação parece encontrar apoio textual no escrito Religião nos limites da simples razão:

Seria uma contradição que a comunidade política tivesse de forçar [zwingen] seus cidadãos a entrar numa comunidade ética, pois esta última, já no seu conceito, traz consigo a liberdade quanto a toda coação. [...]

\footnotetext{
${ }^{7}$ Nesse sentido, minha interpretação vai de encontro àquela sugerida por Pinzani (2009, p. 292).
} 
Mas o legislador que quisesse orientar através de coação [durch Zwang] a constituição para fins éticos não somente produziria o contrário da constituição ética, como também minaria e tornaria insegura sua constituição política. ( $R G V$, AA 06: 95f)

Contudo, o que está em jogo nessa passagem é, por um lado, a impossibilidade de se constranger [zwingen] os cidadãos para entrarem numa comunidade ética e, por outro, a impossibilidade da própria constituição política de um Estado constranger os seus cidadãos para promoção de fins éticos. Ora, de fato, para o bom funcionamento do Estado de direito, é importante que as leis sejam administradas tendo em vista apenas a liberdade externa e as leis do direito. Mas Kant não está afirmando que, se um Estado tiver uma política educativa voltada para promoção da formação moral do cidadão isso promoverá contradição e insegurança jurídica e política. O ponto desse excerto é que a institucionalização jurídica de fins éticos leva à contradição, e não que o Estado deva se abster de oferecer um plano pedagógico integrado que promova uma educação para a liberdade, ou ainda uma educação moral. O problema seria exigir juridicamente, isto é, por constrangimento legal, uma postura é interna. Dito isso, "toda comunidade política pode decerto desejar que nela se encontre também um domínio sobre os ânimos segundo leis de virtude; pois onde os seus meios de coação não chegam (...) ali operariam as disposições de ânimo" ( $R G V$, AA 06: 95f $)^{8}$.

\footnotetext{
${ }^{8}$ A meu ver, a relação entre Religião e Estado ocorre na filosofia kantiana no sentido republicano de uma submissão da religião à política. Kant defende que o Estado, para seu próprio benefício, permita a liberdade religiosa, mas essa liberdade religiosa não é sem limites. Por um lado, Kant recomenda que o Estado promova o esclarecimento indireto dos clérigos permitindo o livre
} 
Outra possível crítica poderia se basear na seguinte passagem:

[é] uma contradição propor-me como fim a perfeição de outrem e considerar-me obrigado a sua promoção. Porque a perfeição de outro homem como pessoa consiste precisamente em que ele mesmo seja capaz de se propor o seu fim de acordo com o seu próprio conceito de dever e é contraditório exigir (propor-me como dever) que deva eu fazer algo que não pode nenhum outro senão ele próprio fazer. (MS, AA 06: 386)

Essa crítica pode ser resolvida, segundo Louden (2000, p. 58), com base na distinção entre adultos e crianças. Tomando-se em conta a consideração de que as crianças precisam ser educadas, segue-se que essa contradição não se aplica à educação infantil, mas apenas a adultos já formados. Outra resposta é sugerida por Wood (1970, p. 74s) e por Kleingeld (1995, p. 57): apesar de não haver um dever de estabelecer a perfeição alheia, não se segue que não haja um dever de promover a perfeição alheia através da criação favorável de condições em que a moralidade possa se desenvolver.

Desse modo, se o Estado não deve agir juridicamente no sentido de garantir a virtude moral, isto é, por via de coerção legal, ainda assim permanece legítimo que ele utilize outros instrumentos institucionais para promover o progresso moral da disposição de ânimo dos seus cidadãos. Veja-se, por exemplo, o que Kant

conflito das faculdades (Teologia e Filosofia), mas também sugerindo que os clérigos deveriam ter aulas de filosofia. Por outro lado, nenhuma religião histórica tem o direito de pregar publicamente contra qualquer princípio do Estado republicano, isto é, atribuindo-se a condição de estar sobre a lei. Mais acerca disso ver Klein (2016a). 
afirma em Teoria e Prática: “(...) se no ensino privado e público, se transformasse em princípio fazer assim [da virtude] uso constante (um método de inculcar os deveres que quase sempre se descurou), a moralidade dos homens bem depressa iria melhorar." (TP, AA 08: 288. 04-18) ${ }^{9}$.

Mas será que, segundo os princípios da filosofia kantiana, seria apenas permissível ou desejável que o Estado tomasse como sua a empreitada de uma educação para a moralidade ou isso poderia ser visto também como um dever do Estado para com o cidadão? Kant afirma que a forma mais fácil para se aproximar do ideal de república noumenon é através de uma forma de governo monárquica, pois quanto mais reduzido for o número de representantes e dirigentes, tanto mais simples será a realização de reformas graduais (cf. ZeF, AA 08: 353). Contudo, ainda que uma monarquia republicana seja a forma mais fácil, penso que se podem colocar sérias restrições de que ela seria a forma mais adequada segundo os princípios morais da própria filosofia kantiana. Como diz Kant no texto sobre o Esclarecimento,

Um homem pode, para a sua pessoa, e mesmo assim somente por um tempo, no que lhe incumbe saber, adiar a ilustração; mas renunciar a ela, quer seja para si, quer ainda mais para seus descendentes, significa lesar e calcar aos pés o sagrado direito da humanidade. O que não é lícito a um povo decidir em relação a si mesmo, menos o pode ainda um monarca decidir sobre o povo, pois a sua autoridade legislativa assenta precisamente no fato de na sua vontade unificar a vontade

${ }^{9}$ Ver também $I a G$, AA 08: 26; Päd, AA 09: 447f.; e Päd, AA 09: 452. 13-17. 
conjunta do povo. (WA, AA 08: 39s. $)^{10}$

Se há um direito da humanidade de buscar o esclarecimento, há também o dever de permiti-lo. Um dos aspectos mais relevantes do esclarecimento se reporta à autonomia e a participação política. Esse é um assunto bastante delicado, que Kant deixou indicado apenas nas entrelinhas dos seus textos. No escrito sobre esclarecimento, Kant utiliza alguns exemplos para explicar o que ele entende por uso privado e uso público da razão. Refere-se ao oficial, ao funcionário da fazenda, ao cidadão, ao clérigo e ao professor. No caso do cidadão, Kant apenas menciona a obrigação de pagar os impostos cobrados, a qual nega a liberdade de um uso privado da razão, mas também menciona o direito do cidadão de fazer um uso público da sua razão, o qual deve seguir o preceito de sempre se comportar como erudito. Mas, quando se refere ao clérigo, Kant afirma algo mais: ele diz que apesar de este estar "obrigado a ensinar os discípulos de catecismo e a sua comunidade em conformidade com o símbolo da Igreja, a cujo serviço se encontra," deve também ter "a plena liberdade e até a obrigação [als Gelehrter hat er volle Freiheit, ja sogar den Beruf dazu] de compartilhar com o público todos os seus pensamentos, cuidadosamente examinados e bemintencionados sobre o que há naquele símbolo." (WA, AA 08: 38) Mais à frente ele acrescenta que, ainda que haja divergência entre o que o clérigo enquanto erudito acredita e aquilo que ele professa enquanto funcionário da Igreja, não pode haver "nada que se oponha à religião interior, pois se acreditasse encontrar aí semelhante contradição, então não poderia desempenhar em consciência seu ministério, deveria renunciar" (WA, AA 08: 38).

${ }^{10}$ Ver também TP, AA 08: 304. 
E conclui, referindo-se agora ao professor, que "é um absurdo, que leva à perpetuação dos absurdos, que os tutores do povo (em coisas espirituais) tenham de ser, por sua vez, menores." (WA, AA 08: 38) Qual a diferença entre o papel de um professor e de um clérigo e aquele de um cidadão? Apesar do silêncio de Kant, a forma como ele constrói os exemplos sugere o que se segue necessariamente dos seus pressupostos teóricos. Os indivíduos em geral escolhem ser professores ou clérigos, mas não escolhem ser cidadãos. Ser cidadão ou súdito de um país é algo que simplesmente lhe ocorre pelo fato de haver nascido em um determinado lugar. A única decisão, que de fato só para poucos é factível, é a de abandonar o país e buscar refúgio alhures. Se existe uma demanda [ein Beruf dazu] do clérigo e do professor para que façam um uso público da sua razão, por que não haveria também uma demanda em relação ao cidadão, no sentido de que cada cidadão deveria em determinados momentos se dispor a fazer um uso público de sua razão a respeito das coisas do Estado, para que se torne esclarecido? No caso do clérigo e do professor, há como que um imperativo hipotético: "se eu quero ser um clérigo ou professor, então devo me comportar passivamente de um modo, mas também tenho a obrigação de me comportar ativamente de outro". Mas, no caso de ser um cidadão e um ser moral, há por princípio um imperativo categórico: "seja um cidadão", "seja um ser moral". Pois se houver uma contradição entre o imperativo hipotético de "Se eu quero ser um clérigo, então tal e tal" em relação ao imperativo categórico "seja moral" na consideração feita por Kant sobre a religião interior, então o imperativo hipotético deve ceder, ou seja, o imperativo categórico prevalece incondicionalmente sobre o imperativo hipotético.

Tendo isso em vista, e levanto em conta que o mote do Escla- 
recimento é "tenha coragem de servir-se do seu próprio entendimento", formado a partir do dever natural para com o desenvolvimento da pessoa e da espécie humana, não seria natural concluir, a partir do imperativo categórico "seja cidadão", que a melhor forma política é aquela que permite não apenas uma maior liberdade de se realizar um uso público da razão, mas também a que permite exercitar o papel pleno de cidadania, enquanto co-legislador e co-governante? Não seria mais conveniente para o esclarecimento se se adotasse a forma de uma Democracia republicana ao invés de uma Monarquia republicana? No ensaio sobre Esclarecimento, Kant parece apontar para a necessidade de um progresso que culmine num modelo político participativo adequado à maioridade da espécie humana.

Pode-se estabelecer um vínculo entre a convocação ou chamado (ein Beruf dazu) para que se faça uso público da razão com uma formulação conceitual problemática no início da Metafísica dos costumes. Na introdução dessa obra, Kant afirma que "uma filosofia prática, que não tem como objeto a natureza, mas a liberdade do arbítrio, pressuporá e requererá uma metafísica dos costumes: quer dizer, ter uma tal metafísica é em si mesmo um dever, e cada homem tem-na também em si próprio, se bem que em regra só de um modo obscuro [dunkle Art]" (MS, AA 06: 216). Ora, o que significa afirmar que cada homem tem o dever de ter em si uma metafísica dos costumes, se ele já a tem, ainda que de modo obscuro? Ter esse dever somente faz sentido se isso significar que cada um deve ter o dever de ter esclarecido para si próprio essa metafísica, isto é, ter claro para si mesmo quais são os princípios metafísicos, seja da doutrina da virtude, seja da doutrina do direito. No caso especial da doutrina do direito, estar-se-ia falando então que todos os homens deveriam 
se esclarecer não apenas a respeito das leis do seu país, mas dos princípios metafísicos que são os critérios de legitimidade daquelas leis e do fundamento do Estado.

Mas por que todo o indivíduo deveria ter claro para si quais são esses princípios se a sua participação política se reduziria apenas ao cumprimento das leis? Para explicar melhor esse ponto, é conveniente recorrer a uma passagem da Lógica de Jäsche:

Com efeito, é possível distinguir os conhecimentos: 1. Segundo sua origem objetiva, isto é, segundo as fontes a partir das quais apenas um conhecimento é possível. A respeito, todos os conhecimentos são racionais ou empíricos. 2. Segundo a sua origem subjetiva, isto é, a maneira pela qual um conhecimento pode ser adquirido pelas pessoas. Considerados deste último ponto de vista, os conhecimentos são ou racionais ou históricos, não importa como possam ter surgido. Por conseguinte, pode haver algo que objetivamente é um conhecimento racional e que, no entanto, subjetivamente é histórico apenas. No caso de certos conhecimentos racionais, é prejudicial sabê-los de um modo meramente histórico; no caso de outros, ao contrário, isso é indiferente. Assim, por exemplo, o navegante sabe as regras da navegação historicamente a partir das tabelas; e isto basta-lhe. Mas, se o jurista possui a jurisprudência de maneira puramente histórica, então ele não tem a menor aptidão para se tornar um genuíno juiz e, com maior razão, um legislador. (Log, AA 09: 22) 
A situação de cidadão estaria mais para a situação do navegante ou do legislador? Isto é, o cidadão precisa ter um conhecimento racional dos princípios do direito ou apenas lhe bastaria um conhecimento histórico das leis do seu Estado? Por que deveria o cidadão conhecer os princípios racionais do direito e da virtude? O que Kant diz com relação aos princípios da ética também pode ser dito com relação aos princípios do direito, a saber, que

[a] inocência é uma coisa admirável; mas, por outro lado, é muito triste que ela se preserve tão mal, e se deixe seduzir tão facilmente. É por isso que a própria sabedoria - que de resto consiste mais em fazer ou não fazer do que em saber - precisa também da ciência, não para aprender com ela, mas para assegurar às suas prescrições entrada nas almas e dar-lhes estabilidade. (GMS, AA 04: 405)

É por isso que "a razão humana vulgar, impelida por motivos propriamente práticos e não por qualquer necessidade de especulação, se vê levada a sair do seu círculo e a dar um passo para dentro do campo da filosofia prática." (GMS, AA 04: 405) Então, de modo análogo ao que ocorre no campo da ética, também no campo do direito o indivíduo, enquanto co-legislador do seu Estado, não deveria apenas conhecer de modo histórico as leis fundamentais do seu Estado. Se há uma obrigação para todo indivíduo - se esclarecer a respeito da metafísica dos costumes, que de um modo obscuro ele já possui e que também lhe pode ser ensinada ("[q]ue a virtude pode e deve ser ensinada é algo que decorre do facto de ela não ser inata", MS, AA 06: 477) -, então é um dever criar uma condição civil na qual esse es- 
clarecimento possa alcançar seu pleno desenvolvimento. Afinal, por que razão o indivíduo deveria ter esse conhecimento, se ele jamais pudesse assumir o papel de juiz e legislador? O esclarecimento moral acerca dos princípios fundamentais do Estado somente faz sentido se se pensar que o indivíduo terá a oportunidade de participar livremente como um sujeito da política, e não simplesmente permanecer na condição passiva de súdito, senão bastar-lhe-ia apenas um conhecimento meramente histórico do direito. O dever de esclarecimento moral, no que concerne aos princípios do Estado e da cidadania, pode ser traduzido, portanto, no dever e no direito que o indivíduo tem de assumir o papel de um cidadão em uma democracia, quando ele assume de fato, não apenas em perspectiva, a posição de co-legislador. Isso significa que o projeto do Esclarecimento aponta para uma democracia representativa, deliberativa e participativa.

Uma passagem que indica claramente essa compreensão republicana e democrática da realização da liberdade política e moral é encontrada numa nota de rodapé do texto dedicado à religião:

Confesso que não consigo acomodar-me à expressão de que se servem alguns homens prudentes: Certo povo (a caminho da elaboração de uma liberdade legal) não está maduro para a liberdade; os servos de um proprietário rural não estão amadurecidos para a liberdade; e assim também os homens em geral ainda não estão maduros para a liberdade da fé. De acordo com semelhante pressuposto, porém, a liberdade nunca terá lugar; pois não se pode para ela amadurecer se antes não se foi posto em liberdade (há que ser livre para alguém se poder servir convenientemente das próprias 
forças na liberdade). As primeiras tentativas serão, decerto, grosseiras, ligadas até ordinariamente a um estado mais molesto e mais perigoso do que quando se estava sob as ordens, mas também sob a providência, de outro; nunca, porém, se amadurece de outro modo para a razão a não ser por meio dos próprios intentos (que alguém deve realizar na liberdade). ( $R G V, \mathrm{AA}$ 06: 188)

Se é um direito e também um dever de todo indivíduo se preparar para assumir o papel de co-legislador em uma República democrática, não cabe aos cidadãos individualmente iniciar e conduzir essa mudança. Nesse sentido, Kant assevera que "esperar um dia, por tarde que seja, a realização de um produto político, como aqui se imagina [A Atlântida de Platão, a Utopia de Morus ou a Oceana de Harrington] é um doce sonho; aproximar-se sempre mais dele é não só pensável, mas até onde se pode harmonizar com a lei moral, é o dever, não dos cidadãos, mas do chefe de Estado." (SF, AA 07: 92n.) É o dever do chefe de Estado introduzir gradualmente as mudanças, não apenas relativas à reformulação das instituições políticas, mas também e principalmente, ir educando e esclarecendo gradualmente o povo para que ele saiba como agir quando lhe for entregue a responsabilidade de se auto legislar e se autogovernar. Do contrário, sem essa preparação, seriam eles obstinados à sublevação e tristes consequências poderiam ser esperadas, exatamente como o predizem os falsos adivinhos políticos, pregadores de uma história abderitista (cf. SF, AA 07: 82), os quais atuam como moralistas políticos, isto é, políticos que "forjam uma moral conveniente às vantagens do homem de Estado." (ZeF, AA 08: 372).

$\mathrm{O}$ direito do povo de se esclarecer politicamente e o dever do 
Estado de promover esse esclarecimento precisam ser compreendidos no mesmo sentido do direito à liberdade do uso público da razão. Trata-se de um direito e de um dever que não são constitutivos da Doutrina do Direito. São direitos e deveres naturais, que só podem ser negligenciados por um tempo, pois são fundamentais para haver um progresso contínuo da espécie humana e das instituições políticas. Trata-se de condições que regulam politicamente a aplicação da Doutrina do Direito. Se este não for respeitado, o povo não tem o direito de constranger fisicamente o governante; e se não é mais sobre o direito que se fala, então se dá o "salto morale" da razão, a saber, "quando não se fala sequer do direito, mas apenas da força, o povo poderia também tentar a sua e assim tornar insegura toda a constituição legal." (TP, AA 08: 306)

É nesse contexto que deve ser lida a seguinte passagem do texto Teoria e prática:

O modo de pensar é patriótico quando cada qual no Estado (sem excetuar o chefe) considera a comunidade como o seio materno, ou o país como o solo paterno de que provém e no qual nasceu, e que deve deixar também atrás de si como penhor precioso para unicamente preservar os direitos do mesmo mediante leis da vontade comum, mas não para se sentir autorizado a dispor dele segundo seu capricho incondicional. ( $T P$, AA 08: 291)

Esse modo de pensar patriótico não tem nada a ver com o modo de pensar nacionalista, pois não se trata de um gosto estético ou sensível por costumes, hábitos e comportamentos de um determinado povo; mas também não é tão geral que não te- 
nha um contexto histórico e geográfico específico, isto é, que seja um modo de pensar cosmopolita. O modo de pensar patriótico se refere a uma atitude política com relação ao seu próprio país, pois é nele que o indivíduo é cidadão, possui direitos e deveres, e é nesse âmbito que ele deve se engajar politicamente. O modo de pensar e de agir cosmopolita é realizado apenas de modo indireto pelos indivíduos, pois em relação aos cidadãos de outros Estados o agente principal é o Estado. Nesse caso, o modo de pensar patriótico deve ser tal que não exclua um modo de pensar cosmopolita, sendo que ambos devem se complementar ${ }^{11}$.

O modo de pensar patriótico não está vinculado aos aspectos históricos, culturais, mas ao modo como o indivíduo compreende as instituições políticas do seu Estado e de como se relaciona com elas. Esse modo de pensar pode ser explicado a partir da postura do agente, que atua motivado pelo espírito da lei e não apenas pela sua letra. Essa atitude, que denomino aqui de virtude moral $^{12}$, é descrita por Kant na Metafísica dos Costumes:

\footnotetext{
${ }^{11}$ Para uma caracterização do patriotismo kantiano como uma forma de patriotismo cívico, ver Kleingeld (2000).

${ }^{12}$ Utiliza-se aqui o termo "virtude moral", pois ele parece se adequar melhor à proposta de Kant de uma Metafísica dos costumes. Por um lado, esse modo específico de pensar não pode ser entendido como uma virtude cívica no senso da teoria republicana tradicional, visto que ele está fundado na razão e não em um modo de pensar e sentir que seja mais ou menos específico de um grupo histórico, social e cultural (cf. Pinzani, 2009, p. 302). Por outro lado, "virtude moral" é distinta dos dois deveres de virtude que Kant apresenta na Doutrina da virtude, pois eles focam na perfeição individual e não visam diretamente as instituições relacionadas com o Direito e a Política. Nomear esse tipo específico de virtude de "moral" é coerente com o conceito kantiano de moral, o qual abarca tanto o direito, quanto a ética. Outro aspecto que precisa ser considerado é que, a partir da perspectiva da filosofia da história de Kant, o fim do progresso precisa estar relacionado e mediado por instituições políticas. E essa descrição de
} 
Se bem que a conformidade das ações ao direito (ser um homem respeitador da legalidade) não constitua algo meritório, é meritória sim a conformidade à máxima de tais ações como deveres, isto é, o respeito pelo Direito. Pois, desse modo, o homem propõe-se como fim seu o direito da Humanidade ou também dos homens, e amplia assim o seu conceito de dever para além do conceito daquilo que é devido (officium debiti): pois alguém, com base no seu direito, pode muito bem exigir de mim ações conformes à lei, mas não que esta contenha ao mesmo tempo o móbil dessas ações. $(M S, \text { AA 06: 390f. })^{13}$

Essa passagem da Metafísica dos costumes ilustra alguns aspectos do modo de pensar patriótico, a saber, sua forma de relação com o Direito, o qual se incorpora em primeira instância nas instituições e leis do seu Estado às quais o cidadão deve respeitar e não apenas temer, e sua relação com o respeito aos direitos da humanidade, ou mais especificamente, o dever de atuar politicamente de modo a defender a posição de que seu Estado sempre atue com relação aos seus membros e com relação a outros Estados de modo a respeitar a pessoa moral e o direito da humanidade. Há assim uma convergência do modo de pensar patriótico e republicano com a atuação por respeito às leis do Direito.

uma virtude moral pode e deve ser promovida pelas instituições políticas no mesmo sentido de que as instituições políticas são aperfeiçoadas por pessoas dotadas de virtude moral.

${ }^{13}$ Ver também MS, AA 06: 220-221. 


\section{Alguns princípios para uma educação pública em direção à virtude moral}

A forma como o projeto de uma educação pública deve ser implementado é um tema bastante delicado, pois, dependendo de como tal projeto for realizado, ele pode não apenas se frustrar, como também produzir o contrário do que seria o esclarecimento político e moral dos cidadãos. Kant alerta para isso na última nota de Antropologia de um ponto de vista pragmático:

Faz parte do caráter de nossa espécie que, aspirando à constituição civil, necessite da disciplina de uma religião, a fim de que o que não pôde ser alcançado pela coerção externa seja realizado pela interna (da consciência), pois a disposição moral do homem é utilizada politicamente pelos legisladores como uma tendência que faz parte do caráter da espécie. Mas, se nessa disciplina do povo, a moral não antecede a religião, esta se assenhora daquela, e a religião estatutária se torna um instrumento do poder do Estado (política) sob déspotas crentes; um mal que inevitavelmente desvirtua o caráter e leva a governar equivocadamente. (Anthr., AA 07: 332)

Para evitar essa consequência degenerada de um projeto de ensino público da virtude moral, alguns princípios importantes devem ser observados. Cabe aqui destacar três. A educação precisa ser pautada: a) no conceito de dever e não no conceito de felicidade; b) em princípios refletidos e não em cálculos de vantagens, hábitos e imitação de exemplos; c) na aprendizagem e no exercício contínuo do uso público da razão. 
Primeiro princípio: evitar uma educação paternalista, que imponha um conceito de vida boa ou de felicidade para os cidadãos. O principal intuito de um Estado deve ser preservar a liberdade e não impor a felicidade. Um governo que colocasse a felicidade ou a benevolência como seu princípio seria um governo paternalista e despótico, assim como o projeto pedagógico a ele vinculado, pois trataria seus súditos como eternas crianças, obrigando-lhes a se comportar de modo passivo e os mantendo no estado de menoridade. A constituição de tal Estado "suprime a liberdade de todos os seus súditos, os quais, por conseguinte, não têm direito algum" ( $T P$, AA 08: 291), e as crianças educadas segundo esse princípio seriam violadas no seu direito de experimentar e escolher diversas possibilidades de felicidade e de conceitos de vida boa. Na constituição de um estado republicano e na educação por ele proporcionada, "fica ao arbítrio de cada um buscar a sua felicidade no caminho que lhe parecer melhor, contanto que não cause dano à liberdade legal geral, por conseguinte, ao direito dos outros co-súditos" (TP, AA 08: 298). Portanto, a única coisa que a educação patriótica deve ensinar com relação à felicidade é que qualquer que seja o conceito de felicidade que alguém assumir, esse sempre deve respeitar o princípio de que a busca dessa sua felicidade não cause dano à liberdade legal geral, isto é, aos princípios metafísicos do direito e as leis positivas do Estado.

Segundo princípio: as crianças devem aprender a agir pelo valor intrínseco dos princípios do direito e não pelas vantagens advindas dessa atuação ou simplesmente repetindo ou imitando o comportamento alheio. O primeiro aspecto desse princípio é enunciado claramente na seguinte passagem:

Se a experiência histórica até agora não quis provar o 
bom êxito das doutrinas da virtude, a culpa cabe precisamente ao falso pressuposto de que o móbil extraído da ideia do dever é em si mesmo demasiado sutil para a concepção comum, ao passo que, pelo contrário, a ideia mais grosseira, derivada de certas vantagens a esperar neste mundo e até num mundo futuro (sem atender à própria lei como móbil), atuaria com mais força sobre o ânimo; e ao fato de até agora se ter dado a preferência para o princípio da educação e da pregação no púlpito, à ânsia pela felicidade, em confronto com aquilo de que a razão faz a condição suprema, isto é, merecer ser feliz. (TP, AA 08: 288)

Kant acredita que o ensino da lei moral, seja na sua formulação ética ou jurídica, tem na sua sublimidade muito mais força do que todo o conjunto de móbiles sensíveis que se possa coletar. Mais do que isso, vincular o agir moral a vantagens seria atribuir "à moralidade móbiles que a minam, e destroem toda a sua sublimidade, juntando na mesma classe os motivos que levam à virtude e os que levam ao vício, e ensinando somente a fazer o melhor cálculo, mas apagando totalmente a diferença específica entre virtude e vício." (GMS, AA 04: 442) Segue-se que "a moralidade tem que ter tanto mais força sobre o coração humano quanto mais pura ela for apresentada"( $K p V$, AA 05: 156), sem mescla de intenções relativas ao próprio bem-estar. Somente assim, "o aprendiz é, contudo, mantido atento à consciência da sua liberdade." ( $K p V$, AA 05: 160)

O segundo aspecto desse princípio é não descurar dos próprios princípios do direito, e tentar suplantar a sua compreensão e reconhecimento simplesmente sugerindo a imitação de exemplos. $\mathrm{Na}$ Fundamentação da metafísica dos costumes Kant alerta que 
"a imitação não tem lugar algum em matéria moral, e os exemplos servem apenas para encorajar, isto é, põem fora de dúvida a possibilidade daquilo que a lei ordena, tornam intuitivo aquilo que a regra prática exprime de maneira mais geral, mas nunca podem justificar que se ponha de lado seu verdadeiro original, que reside na razão e que nos guiemos por exemplos" ( $G M S$, AA 04: 409). Em outras palavras, "propor a crianças a título de modelo ações como nobres, magnânimas e meritórias, na crença de por uma infusão de entusiasmo conquistá-las para as mesmas, é completamente contraproducente." ( $K p V$, AA 05: 157) Isso por que os autores das referidas ações são apresentados como heróis, muito distantes da realidade e da observação de leis morais mais simples. Além disso, a simples imitação de atos alheios pode produzir um hábito, mas não um hábito livre enquanto equivalente da virtude. O primeiro, enquanto simples costume e hábito não moral, "se converteu em necessidade por repetição frequente da ação" e é apenas uma disposição do arbítrio em repetir determinadas ações que são conformes a lei. Já o hábito livre, enquanto sinônimo de virtude, pode ser definido segundo a constância de agir segundo a representação da lei, sendo, nesse caso, uma disposição da vontade "a qual, com a regra que adota, é ao mesmo tempo uma faculdade de desejar universalmente legisladora" ( $M S, 06: 407)$.

Mas isso não significa que os exemplos não tenham valor. Kant chama a atenção para a importância do bom exemplo dado pelo professor: "a imitação é para o homem ainda inculto a primeira determinação da vontade para aceitar as máximas que subsequentemente faz suas." ( $M S$, AA 06: 479) Mas a força do exemplo possui limites na medida em que ele não permite formar nenhuma máxima: 
[o] bom exemplo (a conduta exemplar) não deve servir de modelo, mas tão-somente como prova de que é factível aquilo que é prescrito pelo dever. Portanto, aquilo que tem que proporcionar ao professor a bitola infalível da sua atividade educativa não é a comparação com qualquer outro homem (tal como é), mas a comparação com a ideia de como deve ser (com a ideia de humanidade), ou seja, a comparação com a lei. (MS, AA 06: 479)

Terceiro princípio: exercício contínuo da prática de um uso público da razão. A importância da contínua reflexão e investigação moral para o aprimoramento das virtudes éticas é equivalente à importância do exercício do correto uso público da razão para a política e a virtude moral. A liberdade do uso público da razão é um direito natural que não deve ser violado. Mas isso não significa que seja um uso sem regras e limites. A liberdade do uso público da razão é equivalente a uma liberdade republicana e não a uma liberdade bárbara e selvagem e, por isso, também deve ser aprendida e exercitada, para que dela se faça um bom uso.

A definição kantiana de uso público da razão é bastante peculiar: trata-se "daquele que qualquer um, enquanto erudito, dela faz perante o grande público do mundo letrado" (WA, AA 08: 37). Esse uso supõe tacitamente que, num certo contexto, exista uma comunidade de iguais em que o diálogo seja estabelecido através de princípios comuns. Percebe-se isso primeiramente porque Kant ressalta que só pode fazer um uso público da razão aquele indivíduo que se comporta como erudito no assunto em questão e, além disso, que ele só pode ocorrer perante o grande público do mundo letrado. Essa restrição não tem intenção de 
estabelecer uma espécie de distinção mediante a erudição, mas procura evitar que o uso público da razão descambe para uma mera exposição de opiniões irrefletidas e sem sentido. Como o público do erudito é o grande público do mundo letrado, isso significa que o uso público da razão precisa considerar tanto os princípios de um debate racional, visto que não se poderia esperar menos de uma comunidade de eruditos, quanto os conhecimentos acumulados e as perspectivas adotadas pela comunidade em questão.

Para que o uso público da razão seja verdadeiramente livre, ele não pode sofrer constrangimento externo, isto é, deve ser regulado apenas por princípios internos à comunidade. Isso significa que o governo ou o Estado não devem exercer qualquer força sobre o uso público da razão: "Caesar non est supra grammaticos" (WA, AA 08: 40). Mas isso também significa que, quando houver divergências entre os participantes de um debate público, não se tem permissão para solicitar qualquer interferência ou auxílio externo, pois, nesse caso, haveria o que Kant chama de um conflito ilegal (cf. SF, AA 07: 29-32). A ilegalidade decorre do apelo aos preconceitos e aos sentimentos da massa ou aos sentimentos e preconceitos do legislador, os quais ignoram o assunto em questão ou não estão dispostos a seguir as regras do bom uso público da razão. Então, o conflito deixa de ser um debate e se transforma em disputa ou em mera discussão. Numa disputa o que importa é vencer a qualquer custo, enquanto que um debate tem sempre como princípio fundamental a intenção de chegar à verdade ou o mais próximo possível dela ${ }^{14}$.

\footnotetext{
${ }^{14} \mathrm{~A}$ caracterização da Lógica e da Filosofia como a Arte de disputar é severamente criticada por Kant na Lógica (cf. Log, AA 09: 16s). Da forma como Kant apresenta a crítica, pode-se expandi-la para qualquer debate
} 
A ilegitimidade do uso público da razão ocorre também quando há constrangimentos internos. Esse constrangimento ocorre quando há apelo a argumentos de autoridade ou a alguma suposta capacidade de compreensão superior (intuição intelectual ou revelação sobrenatural). Sobre o primeiro caso, Kant oferece um exemplo em matéria de religião, isto é, quando "há cidadãos que se arrogam o papel de tutores dos outros, e, em vez de argumentos, sabem banir qualquer exame da razão mediante uma impressão inicial sobre os espíritos, por meio de fórmulas de fé acompanhadas do receio de uma investigação de cunho pessoal" (WDO, AA 08: 145). Sobre o segundo tipo de coação, Kant pensa no caso do gênio e de sua exaltação, a qual tem a máxima de um uso sem lei da razão (WDO, AA 08: 145) ${ }^{15}$.

Mas a não submissão de um indivíduo à autoridade do pensamento de outrem não significa que a liberdade de pensamento seja uma recusa completa da opinião de outrem, ou mesmo da legitimidade da coerência com o pensamento alheio. Em outras palavras, se, por um lado, o uso público da razão exige a recusa de um debate baseado em argumentos de autoridade, por outro, ele não conduz o indivíduo a uma espécie de "egoísmo lógico"16, o qual traria consigo o relativismo e o ceticismo absoluto. A verdadeira liberdade, "(...) longe de possuir uma autoridade ditatorial, consiste sempre no simples consenso de cidadãos livres, quando cada um tem que poder externar, sem constrangimento algum, as suas objeções e até o seu veto." ( $K r V$, B 766) Em outras palavras, o uso público da razão requer que todos ajam como concidadãos de direitos e deveres iguais ${ }^{17}$.

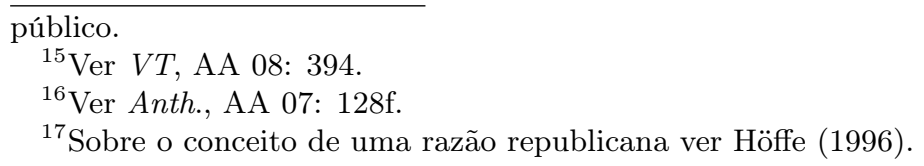


Se se tomar emprestado os critérios que Kant apresenta para qualificar uma constituição republicana no âmbito político, então se pode dizer, mutatis mutandis, que a constituição republicana que deve regular o uso público da razão precisa se basear em três princípios: primeiro, da liberdade dos seus membros, isto é, da capacidade de não obedecer a qualquer lei senão àquela que se pode consentir; segundo, da dependência de todos em relação a uma única legislação comum; terceiro, da igualdade dos mesmos, de forma que ninguém possa vincular juridicamente outro sem que ele se submeta simultaneamente e da mesma forma àquela lei (cf. ZeF, AA 08: 349ff) ${ }^{18}$. Em síntese, o uso público da razão pressupõe sempre uma via de mão dupla, na qual se submete as mesmas leis, sem privilégios e por livre escolha. Ao se fazer um uso da liberdade do público de sua razão, aceitase imediatamente a condição de um cidadão de uma república, cujas leis são constantemente fiscalizadas e esclarecidas pelos filósofos. A via de mão dupla exige que algo seja sempre passível de diálogo e de debate. O uso público pressupõe, portanto, uma determinada atitude do indivíduo e um determinado meio para que se realize. Ao se desconsiderar qualquer uma dessas duas condições, a legitimidade do uso público fica comprometida.

A partir do que Kant afirma sobre a aprendizagem dos deve-

\footnotetext{
${ }^{18}$ Toda legislação necessita de guardiões. No caso da legislação da Razão republicana, Kant atribui esse papel à faculdade da filosofia e aos filósofos. A figura do filósofo representa aqueles cidadãos que, por se dedicarem ao estudo cuidadoso da razão humana e de seus diversos empreendimentos teóricos, além do seu "compromisso originário' com a verdade e de sua desvinculação com os cargos de poder, velam atentamente pelas leis. Mas isso não lhes atribui privilégio algum, pois também eles devem se submeter segundo os três princípios àquela constituição, da mesma forma que todos os seus concidadãos e com os princípios que regem a comunidade dos filósofos, isto é, se comprometer a não realizar um uso falacioso de argumentos.
} 
res de virtude, conclui-se que a aprendizagem desses princípios, pelos quais o uso público da razão deve se regular, precisaria seguir inicialmente o modelo catequético no qual o professor interroga e o aluno responde. Mas uma vez aprendidos os princípios que legitimam o uso público da razão, os alunos devem exercitar sua razão através de um ensino dialógico (onde ambas as partes perguntam e respondem uma à outra) (cf. $M S$, AA 06: 479ss). Nesse caso, as próprias regras do uso público da razão podem ser examinadas e avaliadas. Por exemplo, uma vez os alunos tenham aprendido de modo histórico as regras do uso público da razão e as leis positivas do seu país, podem começar a exercitar o uso público da sua razão a respeito do seu futuro papel enquanto cidadãos, por meio de um debate constante a respeito da legitimidade das leis positivas com relação aos princípios metafísicos que garantem a própria legitimidade do direito, juntamente com as considerações históricas e antropológicas que devem orientar o processo de uma doutrina do direito exercitada, encontrando uma forma de combinar o dever e a prudência, e chegando assim ao conceito de uma sabedoria política.

\section{Considerações finais}

É possível afirmar que o ensino do modo de pensar patriótico e republicano, ou ainda, o ensino de uma virtude moral, não deve ocorrer apenas no âmbito privado, mas também na esfera do ensino público. Para Kant, cabe ao Estado republicano e democrático, o modelo mais legítimo de estado e de governo, a execução de um plano conjunto para uma instrução pública da virtude. Ela não seria uma educação cívica, pois não está em questão apenas o ensino das leis positivas do país, mas envolve 
também o ensino dos princípios da doutrina do direito e dos deveres de virtude. Além disso, o próprio ensino moral deveria ser ao mesmo tempo o ensino da liberdade, isto é, não ocorreria com base nas consequências boas da virtude e as consequências ruins do vício, mas sim a partir da legitimidade dos princípios da ação, os quais sempre devem estar fundados na lei moral e no princípio da autonomia (cf. MS, AA 06: 482f.). Todos esses aspectos republicanos e democráticos se conciliam com o aspecto liberal do pensamento kantiano. Primeiro, porque os deveres de virtude não estão baseados no princípio material da felicidade, mas na lei moral que é universal; segundo, porque o Estado não coagiria os indivíduos ao modo de pensar patriótico e moral, isto é, esse modo de pensar não seria exigido legal e juridicamente dos cidadãos, mas apenas a conformidade externa de suas ações com a lei. Portanto, o Estado apenas ensinaria e promoveria os deveres morais, deixando aos indivíduos o direito de realizá-los da forma que melhor lhes convenha, desde que cumpram as leis positivas. Nesse sentido, o Estado republicano democrático, modelo que melhor expressa os princípios morais da filosofia kantiana, pode ser compreendido também como um liberalismo republicano, isto é, trata-se de um modelo político cujo principal objetivo é a garantia da liberdade dos indivíduos, a qual somente pode se efetivar de forma adequada e legítima por uma política e uma atitude moral republicana. Se o Estado não tomar como sua política a implementação do ensino público da moral, haverá uma estagnação do progresso político e social em direção à realização da liberdade. A atuação do antagonismo social (a sociabilidade insociável) se limita à criação do Estado e à formação de instituições políticas. Mas o aprimoramento dessas instituições depende da virtude dos indivíduos. 
Kant reconhece isso explicitamente quando afirma que apenas um político moral pode produzir uma verdadeira república (cf. $Z e F$, AA 08: 377). A educação dos futuros cidadãos deve ser pensada e focada no que eles devem ser, não no que eles são.

\section{Referências bibliográficas}

GERHARDT, V. Ausgeübende Rechtslehre. Kants Begriff der Politik. In: Kant in der Diskussion der Moderner. Schönrich, Gerhard; Kato, Yasushi (Org.). Frankfurt am Main: Suhkamp, 1996, 464-488.

HÖFFE, O. Eine republikanische Vernunft. Zur Kritik des Solipsismus-Vorwurfs. In: Kant in der Dikussion der Moderne. Schönrich, Gerhard; Kato, Yasushi (Org.). Frakfurt: Suhrkamp a. M., 1996, 396-407.

KANT, I. Gesammelte Schriften. Hrsg.: Bd. 1-22 Preußische Akademie der Wissenschaften; Bd. 23 Deutsche Akademie der Wissenschaften zu Berlin; ab Bd. 24 Akademie der Wissenschaften zu Göttingen. Berlin: Walter de Gruyter, 1900ff. . Antropologia em ponto de vista pragmático (Anth.) Trad.

Clélia Aparecida Martins. São Paulo: Iluminuras, 2006.

. "Resposta à pergunta: que é esclarecimento?" (WA)

Trad. Artur Morão. In: A paz perpétua e outros opúsculos. Lisboa: Edições 70, 2004.

___. O conflito das faculdades. (SF) Trad. Artur Morão. Lisboa: Edições 70, 1993.

. Metafísica dos costumes. (MS) Trad. José Lamego. Lis-

boa: Calouste Gulbenkian, 2005.

. Religião nos limites da simples razão. Trad. Artur Morão. Lisboa: Edições 70, 1992.

___. Fundamentação da metafísica dos costumes. (GMS) 
Trad. Paulo Quintela. In: Kant II. São Paulo: Abril Cultural, 1980.

cosmopolita". (IaG) Trad. Artur Morão. In: A paz perpétua e outros opúsculos. Lisboa: Edições 70, 2004.

- Crítica da razão prática. (KpV) Trad. Valerio Rohden. São Paulo: Martins Fontes, 2002.

___. Crítica da razão pura. (KrV) Trad. da edição B de Valerio Rohden e Udo Baldur Moosburger. In: Kant I. São Paulo: Abril Cultural, 1980.

. Crítica da faculdade do juízo. (KU) Trad.Valerio Rohden e António Marques. 2.ed. Rio de Janeiro: Forense Universitária, 2002.

. Lógica. [Log] Trad. Guido Antônio de Almeida. 2.ed. Rio de Janeiro: Tempo Brasileiro, 1999. ___. "Começo conjectural da história humana" (MAM) Trad. Joel Thiago Klein. In: Ethic@, v.8, n.1, 2009, 157-168.

. Pedagogia. (Päd) Trad. Francisco Cock Fontanella. 4.ed. Piracicaba: UNIMEP, 2004. ___. Reflexionen zur Anthropologie. (Refl) Bd. 15.

"Sobre o dito comum: Isso pode ser correto na teoria, mas não vale na prática". (TP) Trad. Artur Morão. In: A paz perpétua e outros opúsculos. Lisboa: Edições 70, 2004.

. Von einem neuerdings erhobenen vornehmen Ton in der Philosophie. (VT) Trad. Valerio Rohden. In: Studia Kantiana, n.10. 152-170. 2010.

. "Que significa orientar-se no pensamento?" (WDO) Trad. Artur Morão. In: A paz perpétua e outros opúsculos. Lisboa: Edições 70, 2004.

_-_. "A paz perpétua" (ZeF). Trad. Artur Morão. In: A paz 
perpétua e outros opúsculos. Lisboa: Edições 70, 2004.

KLEIN, J. T. Die Weltgeschichte im Kontext der Kritik der Urteilskraft. In: Kant-Studien, v. 104, p. 188-212, 2013a.

- Kant e a Ideia de uma História Universal no Contexto da Crítica da Razão Pura. In: Analytica (UFRJ), v. 18, p. 47-81, 2014c.

___. Liberdade e religião: reflexões kantianas sobre a não coercitividade, a veracidade e a publicidade na relação entre religião e política. In: Ethic@ (UFSC), v. 14, p. 222-251, 2016a.

. The Highest Good and the Practical Regulative Knowledge in Kant's Critique of Practical Reason. In: Con-Textos Kantianos: International Journal of Philosophy, v. 3, p. 210230, 2016b.

KLEINGELD, P. Kantian Patriotism. In: Phylosophy Public affairs, 29, n.4. 313-341, 2000.

. Fortschritt und Vernunft: Zur Geschichtsphilosophie Kants.

Würzburg: Königshausen Neumann, 1995.

LOUDEN, R. B. Kant's impure ethics: from rational beings to human beings. USA: Oxford Universtiy Press, 2000.

PINZANI, A. An den Wurzeln moderner Demokratie: Bürger und Staat in der Neuzeit. Berlin: Akademie Verlag, 2009.

SURPRENANT, C. W. Cultivating Virtue: Moral Progress and the Kantian State. In: Kantian Review, vol. 12, n.1, 90-112, 2007.

WOOD, A. W. Kant's moral religion. London; Ithaca: Cornel University Press, 1970. 